\title{
Arsenic trioxide improves hematopoiesis in refractory severe aplastic anemia
}

\author{
Ning $\mathrm{Li}^{1+}$, Yongping Song ${ }^{1+}$, Jian Zhou ${ }^{1}$ and Baijun Fang ${ }^{1,2^{*}}$
}

\begin{abstract}
We investigated the efficacy of arsenic trioxide (ATO) in patients with refractory severe aplastic anemia (SAA). A total of 5 consecutive adults were enrolled. The patients received ATO at a dose of $0.15 \mathrm{mg} / \mathrm{kg}$ intravenously daily for 5 days every week for 8 weeks. If necessary, a second course was performed after an interval of one week. All patients achieved clinically significant responses to ATO. The overall complete response rate and overall response rate at 17 weeks were 60\% (3/5) and 100\%(5/5), respectively. So treatment with ATO may be a feasible approach in patients with refractory SAA.
\end{abstract}

Keywords: Aplastic anemia, Hematopoiesis, Arsenic trioxide, Adipocytes, Mesenchymal stem cells

\section{To the editor}

No standard therapies are available for patients who have severe aplastic anemia (SAA) that is refractory to immunosuppressive therapy and are ineligible for hematopoietic stem cell transplantation (HSCT). For such patients, an alternative protocol is urgently needed.

From May 2009 to June 2010, a total of 5 consecutive adults (age range, 21-43 years) with a diagnosis of SAA, defined according to standard criteria [1], entered into this study. All of them failed one or two courses of horse or rabbit anti-thymocyte globulin/cyclosporine-based regimens and all of them did not have a suitable donor for HSCT . Other eligibility criteria included adequate hepatic functions, adequate renal function, and adequate cardiac status. The study was approved by the Institutional Review Board.

None of the patients received any immunosuppressive or cytokine therapy for at least 2 month prior to enrollment. Eligible patients received arsenic trioxide (ATO) at a dose of $0.15 \mathrm{mg} / \mathrm{kg}$ intravenously daily for 5 days every week for 8 weeks. If necessary, a second course was performed after an interval of one week. Complete response (CR) was defined as satisfaction of all three

\footnotetext{
* Correspondence: sunfbj@126.com

${ }^{\dagger}$ Equal contributors

${ }^{1}$ Henan Key Lab of Experimental Haematology, Henan Institute of Haematology, Henan Tumor Hospital affiliated to Zhengzhou University, Zhengzhou, China

${ }^{2}$ Henan Institute of Haematology, Henan Tumor Hospital affiliated to Zhengzhou University, 127 Dongming Road, Zhengzhou 450008, China
}

peripheral blood count criteria: (1) absolute neutrophil count $\left(\right.$ ANC) $>1 \times 10^{9} / \mathrm{L}$; (2) haemoglobin $>10 \mathrm{~g} / \mathrm{dL}$; (3) platelet count $>100 \times 10^{9} / \mathrm{L}$. Partial response (PR) was defined as transfusion independence associated with ANC greater than $0.5 \times 10^{9} / \mathrm{L}$, haemoglobin greater than $8 \mathrm{~g} / \mathrm{dL}$, and platelet count greater than $30 \times 10^{9} / \mathrm{L}$. Transfusion dependence was taken as evidence of no response. Relapse was indicated by the requirement for red blood cells or platelets transfusion after having been independent from transfusions for at least 3 months.

The clinical characteristics of patients and outcomes after ATO treatment are summarized in Tables 1 and 2 . The overall response rate at 8 weeks was $100 \%(5 / 5)$ after the initiation of treatment, including $20 \%(1 / 5)$ CR and $80 \%(4 / 5)$ PR. The median time to initial response was 43 days (range, 41- 48 days). Four patients with a PR received a second course of ATO and continued to have clinically significant improvements in blood counts. Two of them eventually met response criteria for CR at 17 weeks after the initiation of treatment. So the overall $\mathrm{CR}$ rate and overall response rate at 17 weeks were $60 \%$ $(3 / 5)$ and $100 \%(5 / 5)$, respectively. Serial bone marrow biopsies showed hematopoietic recovery accompanied by a decrease in adipocyte number in patients after getting a response (Figure 1). Actuarial survival was $100 \%$ at 1 year and $80 \%$ at 2 years. No patient showed evidence of clonal evolution or cytogenetic abnormalities at the last follow-up visit. 
Table 1 Characteristics of patients and outcomes after ATO treatment

\begin{tabular}{|c|c|c|c|c|c|c|c|c|c|}
\hline $\begin{array}{l}\text { Patient } \\
\text { no. }\end{array}$ & $\begin{array}{c}\text { Age/ } \\
\text { gender }\end{array}$ & $\begin{array}{l}\text { Time since } \\
\text { diagnosis } \\
\text { (months) }\end{array}$ & $\begin{array}{l}\text { Previous } \\
\text { Courses of } \\
\text { intensive IST }^{*} \\
\text { (months) }\end{array}$ & $\begin{array}{l}\text { Time since } \\
\text { last intensive } \\
\text { IST (months) }\end{array}$ & $\begin{array}{l}\text { Response } \\
\text { to prior } \\
\text { intensive IST }\end{array}$ & $\begin{array}{l}\text { Time to initial } \\
\text { response to } \\
\text { ATO (days) }\end{array}$ & $\begin{array}{l}\text { Time to } \\
\text { maximum } \\
\text { response to } \\
\text { ATO (days) }\end{array}$ & $\begin{array}{l}\text { The final } \\
\text { response } \\
\text { to ATO }\end{array}$ & $\begin{array}{l}\text { Present } \\
\text { status }\end{array}$ \\
\hline 1 & $21 / M$ & 35 & 2 & 9.8 & Primary refractory & 41 & 56 & $C R$ & $\begin{array}{l}\text { CR and well } \\
34 \text { months }\end{array}$ \\
\hline 2 & $37 / F$ & 71 & 1 & 11 & Relapsed refractory $^{\dagger}$ & 43 & 102 & $P R$ & $\begin{array}{l}\text { PR and well } \\
28 \text { months }\end{array}$ \\
\hline 3 & $43 / \mathrm{M}$ & 38 & 2 & 13.4 & Primary refractory & 42 & 87 & $C R$ & $\begin{array}{l}\text { CR and well } \\
25 \text { months }\end{array}$ \\
\hline 4 & $35 / F$ & 41 & 2 & 9.2 & Primary refractory & 46 & 69 & $C R$ & $\begin{array}{c}\text { Relapsed and } \\
\text { transfusion } \\
\text { dependent }\end{array}$ \\
\hline 5 & $29 / M$ & 63 & 2 & 10.3 & Primary refractory & 48 & 108 & PR & $\begin{array}{l}\text { PR and well } \\
20 \text { months }\end{array}$ \\
\hline
\end{tabular}

$M$, male; F, female; IST, Intensive immunosuppressive therapy; ATO, arsenic trioxide; CR, complete response; PR, partial response.

*IST regimens included horse antithymocyte globulin (ATG), rabbit ATG, cyclophosphamide, and fludarabine.

\#Primary refractory disease was defined as no prior adequate response to IST.

${ }^{\dagger}$ Relapsed refractory disease was defined as a prior adequate response to at least one regimen of IST.

ATO-related toxicities occurred in 1 of 5 with skin reactions (rash, itching, erythema), 2 of 5 with gastrointestinal reactions (vomiting, nausea, diarrhea), 1 of 5 with liver dysfunction, and 2 of 5 with facial edema. All the side effects were modest and responded to symptomatic treatment. No patient discontinued therapy because of ATO-related toxicities.

Studies suggest that bone marrow adipocytes are predominantly negative regulators of the bone marrow microenvironment [2]. Bone marrow adipocytes are less supportive of hematopoiesis than those of other cell types derived from mesenchymal progenitors such as bone marrow myofibroblasts or osteoblasts [3,4]. In addition, it has been shown that ablation of the bone marrow adipocyte compartment can induce osteogenesis [2], which promotes a more supportive environment for hematopoietic reconstitution [2,5]. This is in accordance with the data that surgical removal of the adipocyte-rich marrow induces hematopoietic infiltration and new osteoid and trabecular bone formation in rabbit tibias [6]. Considering that adipocytes and osteoblasts originate from the common precursor, mesenchymal stem cells (MSCs), within the bone marrow, where both display an inverse or reciprocal relationship [7], and that ATO could regulate the adipogenic and osteogenic differentiation of MSCs by significantly inhibiting adipogenic differentiation and enhancing MSCs osteogenic differentiation [8], ATO might be used to improve hematopoiesis in SAA patients.

Recently, we administered arsenic trioxide (ATO) plus cyclosporine in patients with SAA. The overall complete response rate and overall response rate at 17 weeks after the initiation of treatment were $80 \%(8 / 10)$ and $100 \%$ $(10 / 10)$, respectively [9]. This observation prompted us to investigate whether ATO has activity in patients with SAA who have persistent, severe cytopenia after one or more cycles of immunosuppressive therapy. In this study, all patients achieved clinically significant responses to ATO. Therefore ATO could represent a reasonable salvage treatment in those patients with refractory SAA. The current study is being expanded to gain more data on this novel approach.

Table 2 Patients' characteristics before and after ATO treatment

\begin{tabular}{|c|c|c|c|c|c|c|c|c|}
\hline \multirow{2}{*}{$\begin{array}{l}\text { Patient } \\
\text { No. }\end{array}$} & \multicolumn{2}{|c|}{ No. of RBC transfusions per week (mean units) } & \multicolumn{2}{|c|}{ platelet count $\left(\times 10^{9} / \mathrm{L}\right)$} & \multicolumn{2}{|c|}{ Haemoglobin $(g / d L)$} & \multicolumn{2}{|c|}{ ANC $\left(\times 10^{9} / \mathrm{L}\right)$} \\
\hline & $\begin{array}{l}\text { Before ATO } \\
\text { therapy }\end{array}$ & $\begin{array}{l}\text { After maximum } \\
\text { response to ATO }\end{array}$ & $\begin{array}{l}\text { Before ATO } \\
\text { therapy }\end{array}$ & $\begin{array}{c}\text { After } \\
\text { maximum } \\
\text { response } \\
\text { to ATO }\end{array}$ & $\begin{array}{l}\text { Before } \\
\text { ATO } \\
\text { therapy }\end{array}$ & $\begin{array}{c}\text { After } \\
\text { maximum } \\
\text { responseto } \\
\text { ATO }\end{array}$ & $\begin{array}{l}\text { Before } \\
\text { ATO } \\
\text { therapy }\end{array}$ & $\begin{array}{c}\text { After } \\
\text { maximum } \\
\text { response } \\
\text { to ATO }\end{array}$ \\
\hline 1 & 1.8 & Transfusion independence & 9 & 115 & 5.1 & 11.4 & 0.2 & 2.0 \\
\hline 2 & 1.9 & Transfusion independence & 11 & 73 & 5.3 & 8.6 & 0.1 & 0.8 \\
\hline 3 & 2.3 & Transfusion independence & 14 & 138 & 4.9 & 11.2 & 0.3 & 1.9 \\
\hline 4 & 2.6 & Transfusion independence & 9 & 107 & 6.1 & 12.3 & 0.2 & 2.2 \\
\hline 5 & 1.9 & Transfusion independence & 5 & 67 & 5.7 & 8.8 & 0.2 & 0.9 \\
\hline
\end{tabular}

RBC, red blood cells; ATO, arsenic trioxide; ANC, absolute neutrophil count. 

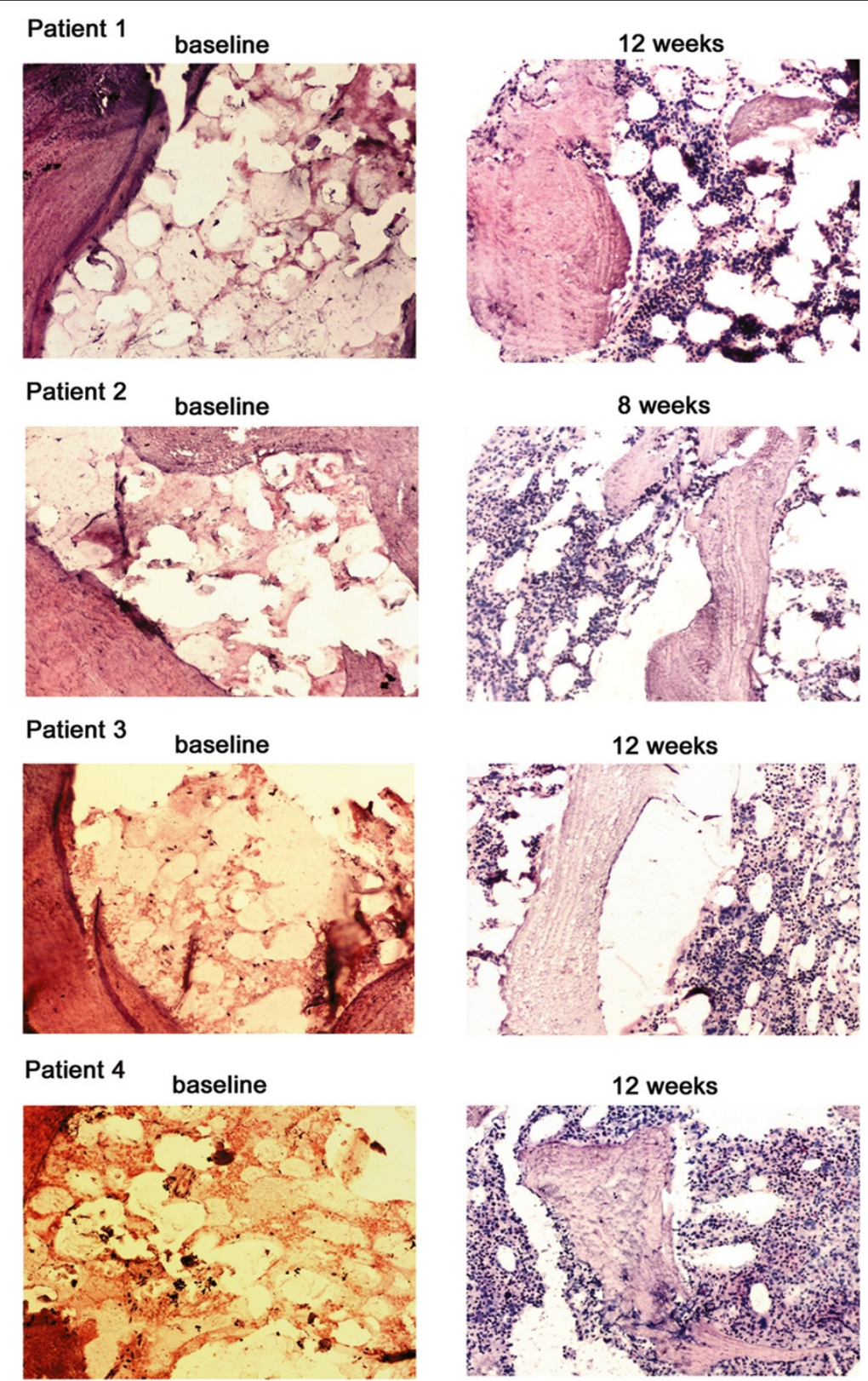

Patient 5 baseline

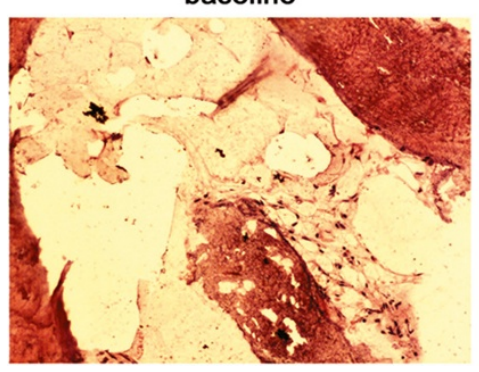

12 weeks

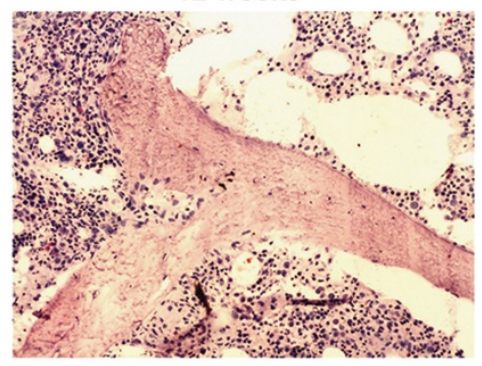

Figure 1 Hematopoietic recovery in five patients with refractory aplastic anemia after arsenic trioxide therapy. Bone marrow biopsy specimens were obtained from the five patients. Specimens from pre- and post-treatment (at 8 weeks) were shown. (Hematoxylin and eosin stain; Original magnification: $\times 100)$ 


\section{Competing interests}

The authors declare that they have no competing interests.

\section{Author contributions}

Study concept and design: BF and NL; Acquisition of data: NL, YS, JZ and BF. Analysis and interpretation of data: BF, NL and YS. Drafting of the manuscript: NL, YS, JZ and BF. All authors have read and approved the final manuscript.

\section{Acknowledgements}

The authors would like to thank all patients for their cooperation. This study was supported by grants from the National Natural Science Foundation of China (No. 30900637) and the National Natural Science Foundation of China (No. 81070398).

Received: 3 October 2012 Accepted: 4 October 2012

Published: 9 October 2012

\section{References}

1. Rosenfeld S, Follmann D, Nunez O, Young NS: Antithymocyte globulin and cyclosporine for severe aplastic anemia: association between hematologic response and long-term outcome. JAMA 2003, 289:1130-1135.

2. Naveiras O, Nardi V, Wenzel PL, Hauschka PV, Fahey F, Daley GQ: Bonemarrow adipocytes as negative regulators of the haematopoietic microenvironment. Nature 2009, 460:259-263.

3. Corre J, Barreau C, Cousin B, Chavoin JP, Caton D, Fournial G, Penicaud L, Casteilla L, Laharrague P: Human subcutaneous adipose cells support complete differentiation but not self-renewal of hematopoietic progenitors. J Cell Physiol 2006, 208:282-288.

4. Nishikawa M, Ozawa K, Tojo A, Yoshikubo T, Okano A, Tani K, Ikebuchi K, Nakauchi H, Asano S: Changes in hematopoiesis-supporting ability of C3H10T1/2 mouse embryo fibroblasts during differentiation. Blood 1993, 81:1184-1192.

5. Calvi LM, Adams GB, Weibrecht KW, Weber JM, Olson DP, Knight MC, Martin RP, Schipani E, Divieti P, Bringhurst FR, Milner LA, Kronenberg HM, Scadden DT: Osteoblastic cells regulate the haematopoietic stem cell niche. Nature 2003, 425:841-846.

6. Tavassoli M, Maniatis A, Crosby WH: Induction of sustained hemopoiesis in fatty marrow. Blood 1974, 43:33-38.

7. Nuttall ME, Gimble JM: Controlling the balance between osteoblastogenesis and adipogenesis and the consequent therapeutic implications. Curr Opin Pharmacol 2004, 4:290-294.

8. Cheng H, Qiu L, Zhang H, Cheng M, Li W, Zhao X, Liu K, Lei L, Ma J: Arsenic trioxide promotes senescence and regulates the balance of adipogenic and osteogenic differentiation in human mesenchymal stem cells. Acta Biochim Biophys Sin (Shanghai) 2011, 43:204-209.

9. Song Y, Li N, Liu Y, Fang B: Improved outcome of adults with aplastic anemia treated with arsenic trioxide plus cyclosporine. $\mathrm{Br} J$ Haematol. In press.

doi:10.1186/1756-8722-5-61

Cite this article as: Li et al:: Arsenic trioxide improves hematopoiesis in refractory severe aplastic anemia. Journal of Hematology \& Oncology 2012 5:61.

\section{Submit your next manuscript to BioMed Central and take full advantage of:}

- Convenient online submission

- Thorough peer review

- No space constraints or color figure charges

- Immediate publication on acceptance

- Inclusion in PubMed, CAS, Scopus and Google Scholar

- Research which is freely available for redistribution 